\title{
Rickettsia japonica sp. nov., the Etiological Agent of Spotted Fever Group Rickettsiosis in Japan
}

\author{
TAKAHIRO UCHIDA, ${ }^{1 *}$ TSUNEO UCHIYAMA,${ }^{1}$ KEIKO KUMANO,${ }^{1}$ AND DAVID H. WALKER ${ }^{2}$ \\ Department of Virology, School of Medicine, University of Tokushima, Tokushima 770, Japan ${ }^{1}$ and \\ Department of Pathology, University of Texas Medical Branch, Galveston, Texas $77550^{2}$
}

\begin{abstract}
We propose the name Rickettsia japonica sp. nov. (with type strain YH $[=$ ATCC VR-1363]) for a serologically specific species of spotted fever group rickettsiae that are pathogenic for humans (J. Infect. Dis. 159:1122-1126, 1989; J. Clin. Microbiol. 28:1177-1180, 1990). The biologic and genomic characteristics of the organism (G+C content, $31.2 \pm 0.7 \mathrm{~mol} \%$ ) are essentially the same as those of other pathogenic spotted fever group rickettsiae, although the $R$. japonica isolates cause a persistent infection in Vero cells for many subcultures.
\end{abstract}

In this paper we formally describe Rickettsia japonica (23, 25), which has been identified as the causative agent of a human disease. The first isolate, strain $\mathrm{YH}^{\mathrm{T}}(\mathrm{T}=$ type strain), was isolated in 1985 from the blood of a patient with febrile exanthematous illness in Japan by using a tissue culture technique (20). Five strains of the causative agent, including strain $\mathrm{YH}^{\mathrm{T}}$, have been isolated from patients that were serodiagnosed as having a spotted fever group (SFG) rickettsiosis (22).

Justification for a new species. The justification for establishing a new species for this organism is based on the current standard method for comparing rickettsial taxonomic types by serologic analysis (23). Experiments involving reciprocal cross-reactions of mouse polyclonal antibodies to strains of the new species and other species of SFG rickettsiae produced by the standard method were carried out to calculate the specificity differences. By using this approach we demonstrated that all five strains belong to a single species that is distinct from all of the previously described SFG rickettsiae that are known to be pathogenic for humans (23). In addition, none of the isolates reacted with mouse monoclonal antibodies that are species specific for other pathogenic SFG rickettsiae (23). Furthermore, the results of Western immunoblotting revealed different electrophoretic mobilities and antigenic reactivities for the major immunodominant high-molecular-weight surface polypeptides of the Japanese isolates and standard pathogenic SFG rickettsial strains (23). Species-specific monoclonal antibodies to $R$. japonica reacted only with strains of $R$. japonica, supporting the conclusion that $R$. japonica is a new species of SFG rickettsiae (25).

Description of Rickettsia japonica sp. nov. Rickettsia japonica (ja. po' ni. ca. N.L. adj. japonica, pertaining to Japan, the country in which the organism was first isolated). In smears from cell cultures, the intracellular organisms are visualized by Gimenez staining or by indirect immunofluorescence with immune sera $(20)$. Gram-negative rods that are 0.4 to 0.5 by 0.8 to $1.5 \mu \mathrm{m}$. The organisms possess an outer slime layer and a trilaminar cell wall with thin outer and thick inner leaflets (24). Obligate intracellular parasite. The organisms carry species-specific epitopes on the surface (25). The organisms also possess an SFG-common antigen that is detectable by monoclonal antibody 3 Y8-B3 (to $R$. japonica

\footnotetext{
* Corresponding author.
}

$\mathrm{YH}^{\mathrm{T}}$ ) that reacts with all of the strains of SFG rickettsiae tested but not with Rickettsia typhi Wilmington (= ATCC VR144). Polyclonal antibodies produced in mice against $R$. japonica react with $R$. typhi only at low titers. On the other hand, sera from some patients infected with $R$. japonica react with $R$. typhi at high dilutions (22).

Growth of $R$. japonica occurs in Vero cells without cytopathic effects, and a carrier state that persists for 20 subcultures of infected cells develops. Carrier Vero cells divide until a monolayer is formed after subculturing in minimal essential medium containing $10 \%$ fetal calf serum and no antibiotics in a $5 \% \mathrm{CO}_{2}$-air incubator at $34^{\circ} \mathrm{C}$. After cocultivation with uninfected Vero cells, all cells enter the carrier state. The organisms in carrier cells are viable after storage at $-80^{\circ} \mathrm{C}$ or in liquid nitrogen when the carrier cells are stored in minimal essential medium containing $5 \%$ dimethyl sulfoxide, $20 \%$ fetal calf serum, and no antibiotics. $R$. japonica differs from other SFG rickettsiae with respect to growth in Vero cells; the strains which we tested have been described previously (23). Rickettsia australis Cutlack, Rickettsia conorii Malish 7, Rickettsia rickettsii $\mathrm{R}$ (= ATCC VR891), and Thai tick typhus rickettsia TT-118 produce cytopathic effects 3 to 6 days after inoculation. Although Rickettsia akari Kaplan (= ATCC VR148) and Rickettsia sibirica 232 cause few cytopathic effects, the infected cells do not grow continuously after subculturing. The growth properties are the same in Vero C1008 (= ATCC CRL1586) cells. Chicken embryo fibroblast primary culture, BHK $21 / 13$, and L929 cells allow $R$. japonica to grow with cytopathic effects. Replication in Vero and BHK 21/13 cells occurs primarily in the cytoplasm and rarely in nuclei. Figure 1 shows ultrathin sections of heavily infected Vero C1008 cells, which were examined with a Hitachi model HU-12 electron microscope as described previously (24).

The plaque morphology produced by $R$. japonica is different from that produced by most other SFG rickettsiae. Infected Vero cells centrifuged at $250 \times \mathrm{g}$ for $5 \mathrm{~min}$ were diluted in sucrose-phosphate-glutamate buffer (1) and plated onto Vero cell monolayers and then overlaid with Leibovitz medium L-15 containing $0.5 \%$ methylcellulose and $5 \%$ fetal calf serum. At intervals during incubation at $34^{\circ} \mathrm{C}$ in an air incubator, the monolayers were simultaneously fixed and stained with a $10 \%$ formalin solution containing $0.5 \%$ crystal violet and washed with water to identify plaques (infectious centers). After 9 to 11 days of incubation, $R$. japonica formed plaques with a targetlike appearance (a dye-stained 


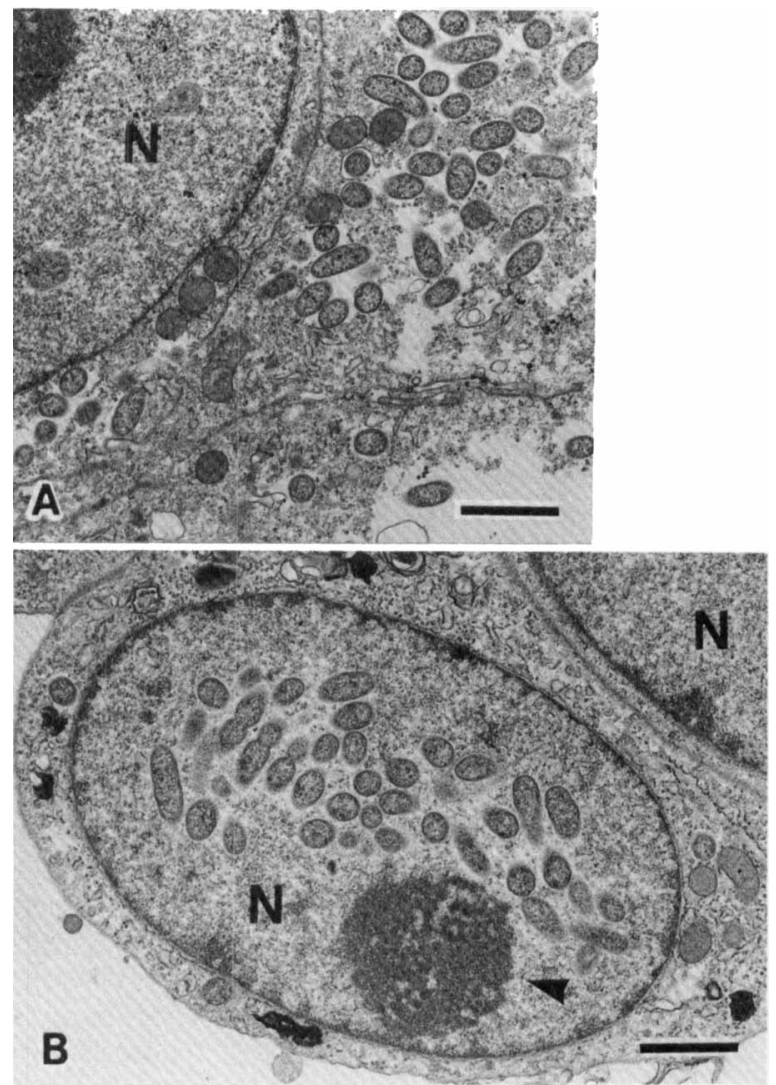

FIG. 1. (A) Rickettsiae in the cytoplasm of heavily infected Vero C1008 cells. (B) Rickettsiae in a nucleus (N). The arrowhead indicates the nucleolus. Bars $=1.5 \mu \mathrm{m}$.

inner spot surrounded by a clear zone). The diameter of the targetlike plaques increased to $2.0 \mathrm{~mm}$ on day 13 . Other SFG rickettsiae produced clear plaques on day $6 ; R$. rickettsii produced plaques with diameters of 1.6 and $2.0 \mathrm{~mm}$ on days 8 and 11 , respectively, while other rickettsiae formed smaller plaques. $R$. akari produced very tiny plaques. When monolayers were overlaid with $0.8 \%$ agarose and stained with neutral red as described previously (2), no plaques were formed by $R$. japonica even after 13 days, while clear plaques with a diameter of $2.5 \mathrm{~mm}$ were produced by $R$. rickettsii after 8 days of incubation. A plaque type variant isolated from a guinea pig after inoculation with $R$. japonica (see below) formed a clear plaque. About 0.01 to $0.001 \%$ of the carrier cells with strain $\mathrm{YH}^{\mathrm{T}}$ produced clear plaques on Vero cell monolayers.

The organisms are pathogenic for guinea pigs. Specificpathogen-free male guinea pigs (strain Hartley, 13 weeks old) were obtained from the SLC Farm, Shizuoka, Japan, and were inoculated intraperitoneally with 10 to $10^{6}$ carrier cells that had been subcultured 9 to 11 times and contained an average of 50 rickettsial particles per cell, which were counted after smears were stained by using the immunofluorescence technique. The rectal temperatures abruptly increased to more than $40^{\circ} \mathrm{C}$; this reaction was accompanied by scrotal swelling 2 to 3 days after inoculation, even if a small dose (10 carrier cells) was inoculated. The fever continued for 2 to 3 days and was followed by defervescence to around $38^{\circ} \mathrm{C}$. Most of the rickettsiae recovered by tissue culturing from the blood during the febrile stage produced
TABLE $1 . T_{m}$ values and $\mathrm{G}+\mathrm{C}$ contents of DNAs ${ }^{a}$

\begin{tabular}{|c|c|c|c|c|}
\hline \multirow{2}{*}{ Organism } & \multicolumn{2}{|c|}{$T_{m}\left({ }^{\circ} \mathrm{C}\right)$ determined: } & \multicolumn{2}{|c|}{$\begin{array}{c}\mathrm{G}+\mathrm{C} \text { content }(\mathrm{mol} \%) \\
\text { determined }^{b}:\end{array}$} \\
\hline & $\begin{array}{l}\text { In this } \\
\text { studyc }\end{array}$ & Previously ${ }^{d}$ & $\begin{array}{l}\text { In this } \\
\text { study }\end{array}$ & Previously \\
\hline$R$. japonica $\mathrm{YH}$ & $82.1 \pm 0.3$ & & $31.2 \pm 0.7$ & \\
\hline R. rickettsii $\mathrm{R}$ & $82.3 \pm 0.2$ & $82.4 \pm 0.2$ & $31.7 \pm 0.5$ & $32.0 \pm 0.5$ \\
\hline E. coli $\mathrm{B}^{e}$ & $90.5 \pm 0.2$ & 90.5 & $51.7 \pm 0.5$ & 51.7 \\
\hline
\end{tabular}

${ }^{a}$ DNAs were extracted from Percoll density gradient-purified rickettsiae by treatments with lysozyme $\left(3 \mathrm{mg} / \mathrm{ml}\right.$ at $37^{\circ} \mathrm{C}$ for $\left.30 \mathrm{~min}\right)$ and proteinase $\mathrm{K}(30$ $\mu \mathrm{g} / \mathrm{ml}$ in $1 \%$ sodium dodecyl sulfate at $50^{\circ} \mathrm{C}$ for $3 \mathrm{~h}$ ), followed by a phenol-chloroform treatment (12) that included DNase-free RNase A treatment $\left(0.1 \mathrm{mg} / \mathrm{ml}\right.$ at $37^{\circ} \mathrm{C}$ for $\left.2 \mathrm{~h}\right)$.

${ }^{b}$ Calculated by using the formula of Marmur and Doty (9).

${ }^{c}$ Means \pm standard deviations for three to five determinations.

${ }^{d}$ Data from references 9 and 17 .

e Ultrapure genomic DNA (Sigma Chemical Co.) was used as a standard.

targetlike plaques; the one exception was a clear-plaque variant that was isolated from a guinea pig which was inoculated with $10^{6}$ carrier cells. Specific-pathogen-free strain $\mathrm{C} 3 \mathrm{H} / \mathrm{HeSlc}$ mice and conventional strain ddY mice (males that were 8 to 12 weeks old) developed inapparent infections after intraperitoneal inoculation; $\mathrm{C} 3 \mathrm{H} / \mathrm{He}$ mouse strains have been reported to be susceptible to $R$. conorii (3). The mice produced antibodies (titers, 1:20 to 1:160) on day 7 , and the titers increased to $1: 320$ to $1: 2,560$ on day 21 after inoculation with $10^{2}$ to $10^{3}$ carrier cells. Chicken embryos died 5 to 7 days after yolk sac inoculation with organisms propagated in chicken embryo fibroblasts $\left(10^{3}\right.$ infected cells) when they were incubated at $33^{\circ} \mathrm{C}$; the maximum yield occurred on day 2 after the death of the chicken embryos.

$R$. japonica exhibited no hemolytic activity when it was assayed with $0.26 \mathrm{mg}$ of protein by using the method of Snyder et al. (14); the organisms which we used were propagated in BHK 21/13 cells and banded at a density of $1.080 \mathrm{~g} / \mathrm{cm}^{3}$ in a Percoll gradient. A control reaction mixture containing the same quantity of $R$. typhi protein resulted in hemolysis, giving an $A_{545}$ of 0.240 .

The buoyant density of $R$. japonica DNA was estimated to be $1.692 \mathrm{~g} / \mathrm{cm}^{3}$. Rickettsial DNA extracted from Percoll density gradient-purified organisms by using the standard phenol-chloroform method (12) was centrifuged with $\mathrm{CsCl}$ in $10 \mathrm{mM}$ Tris $\mathrm{HCl}(\mathrm{pH} 8.0)$ at $290,000 \times g$ for $7 \mathrm{~h}$ at $20^{\circ} \mathrm{C}$ in a type RP55VF2 vertical rotor in a Hitachi model CP56G Himac preparative ultracentrifuge, resulting in a single peak of DNA in a $\mathrm{CsCl}$ gradient. The $\mathrm{CsCl}$ density of the peak fraction, obtained from the refractory index (5), was determined on the basis of a value of $1.710 \mathrm{~g} / \mathrm{cm}^{3}$ for the density of the reference DNA from Escherichia coli B (13). Both strain $\mathrm{YH}^{\mathrm{T}}$ and clear-plaque variant DNAs banded at the same density.

The thermal denaturation temperature $\left(T_{m}\right)$ of DNA from R. japonica was $82.1 \pm 0.3^{\circ} \mathrm{C}(n=5)$. A Hitachi model U-3210 spectrophotometer equipped with a thermoelectric cell holder connected to a model SPR-10 temperature controller and a digital thermometer was used to measure the $T_{m}$ as described by Marmur and Doty (9). In this study we used clear-plaque variant DNA. As Table 1 shows, reference $R$. rickettsii $\mathrm{R}$ DNA, which was extracted and purified as described above, had a $T_{m}$ identical to the value reported previously (17). An $E$. coli B standard DNA also had the $T_{m}$ reported previously (9).

The guanine-plus-cytosine $(\mathrm{G}+\mathrm{C})$ content of $R$. japonica DNA calculated from the $T_{m}$ by using the previously de- 
scribed formula (9) was $31.2 \pm 0.7 \mathrm{~mol} \%$. This value is identical to the values obtained for other SFG rickettsiae (17). The $G+C$ value calculated from the estimated buoyant density by using the equation described by Schildkraut et al. (13) was $32.6 \mathrm{~mol} \%$.

Description of the illness. The illness caused by $R$. japonica is found mainly in the southwestern part of Japan $(4,6-8,15$, $16,18,19,21,26)$; a few cases have been reported in the west-northwest portion of Honshu (10). $R$. japonica causes an illness (Oriental spotted fever) that is similar to boutonneuse fever. A similar agent has been isolated in another laboratory (11) and remains to be identified as $R$. japonica. The vector has not been determined. The full geographic distribution of the organisms remains to be established.

Type strain. Type strain YH (= ATCC VR-1363) of $R$. japonica is the first strain of $R$. japonica that was isolated and has been distributed to the National Institute of Health, Tokyo, Japan, and to prefectural public health laboratories in Japan. All of the strains have the same properties.

We are grateful to Charles L. Wisseman, Jr. (University of Maryland) for his advice and to Akiyoshi Kawamura, Jr. (University of Tokyo) and Hiroshi Tanaka (University of Tokyo) for their encouragement. We also acknowledge Takashi Kobunai (Biological Research Laboratory, Taiho Pharmaceutical Co., Tokushima, Japan) for determining the $T_{m}$ of the DNA.

This work was supported in part by grant 63044102 for joint research from the Monbusho International Scientific Research Program of the Ministry of Education, Science and Culture of Japan, by a grant from the Ohyama Health Foundation, Tokyo, Japan, and by grant AI-22224 from the National Institute of Allergy and Infectious Diseases.

\section{REFERENCES}

1. Bovarnick, M. R., J. C. Miller, and J. C. Snyder. 1950. The influence of certain salts, amino acids, sugars, and proteins on the stability of rickettsiae. J. Bacteriol. 59:509-522.

2. Cory, J., C. E. Yunker, R. A. Ormsbee, M. Peacock, H. Meibos, and G. Tallent. 1974. Plaque assay of rickettsiae in a mammalian cell line. Appl. Microbiol. 27:1157-1161.

3. Eisemann, C. S., M. J. Nypaver, and J. V. Osterman. 1984. Susceptibility of inbred mice to rickettsiae of the spotted fever group. Infect. Immun. 43:143-148.

4. Funato, T., Y. Kitamura, A. Kawamura, and T. Uchida. 1988. Rickettsiosis of spotted fever group encountered in Muroto area of Shikoku, Japan: clinical and epidemiological features of 23 cases. Kansenshogaku Zasshi 62:783-791. (In Japanese.)

5. Ifft, J. B., D. H. Voet, and J. Vinograd. 1961. The determination of density distributions and density gradients in binary solutions at equilibrium in the ultracentrifuge. J. Phys. Chem. 65:11381145 .

6. Iwamoto, K., F. Nishimura, Y. Yoshino, J. Mihara, T. Okabe, H. Kameda, and T. Kubagawa. 1988. A case of spotted fever with central nervous system involvement. Kansenshogaku Zasshi 62:1192-1196. (In Japanese.)

7. Kaiho, I., M. Tokieda, M. Ohtawara, T. Uchiyama, and T. Uchida. 1988. Occurrence of rickettsiosis of spotted fever group in Chiba Prefecture of Japan. Jpn. J. Med. Sci. Biol. 41:69-71.

7a.Kodama, K., T. Matsuo, M. Nakauchi, Y. Kobayashi, Y. Tange, and T. Okada. 1990. Spotted fever group rickettsiosis on Awaji Island, Japan. Kansenshogaku Zasshi 64:504-509. (In Japanese.)

8. Mahara, F., K. Koga, S. Sawada, T. Taniguchi, F. Shigemi, T.
Suto, Y. Tsuboi, A. Oya, H. Koyama, T. Uchiyama, and T. Uchida. 1985. The first report of rickettsial infections of spotted fever group in Japan; three clinical cases. Kansenshogaku Zasshi 59:1165-1172. (In Japanese.)

9. Marmur, J., and P. Doty. 1962. Determination of the base composition of deoxyribonucleic acid from its thermal denaturation temperature. J. Mol. Biol. 5:109-118.

10. Oka, N., Y. Kato, S. Dekio, T. Nishio, A. Itagaki, T. Uchiyama, and T. Uchida. 1990. A case report of spotted fever group rickettsiosis first encountered in Shimane Prefecture, Japan. Kansenshogaku Zasshi 64:136-142. (In Japanese.)

11. Okada, T., Y. Tange, and Y. Kobayashi. 1990. Causative agent of spotted fever group rickettsiosis in Japan. Infect. Immun. 58:887-892.

12. Sambrook, J., E. F. Fritsch, and T. Maniatis (ed.). 1989. Molecular cloning. A laboratory manual, 2nd ed. Cold Spring Harbor Laboratory Press, Cold Spring Harbor, N.Y.

13. Schildkraut, C. L., J. Marmur, and P. Doty. 1962. Determination of the base composition of deoxyribonucleic acid from its buoyant density in CsCl. J. Mol. Biol. 4:430-443.

14. Snyder, J. C., M. R. Bovarnick, J. C. Miller, and R. S.-M. Chang. 1954. Observations on the hemolytic properties of typhus rickettsiae. J. Bacteriol. 67:724-730.

15. Suto, T. 1985. Evidence of spotted fever rickettsial infection in Japan as demonstrated by the indirect immunoperoxidase test. Microbiol. Immunol. 29:1243-1246.

16. Tachibana, N., E. Shishime, A. Okayama, J. Ishizaki, K. Murai, S. Shioiri, K. Tsuda, and T. Oshikawa. 1987. Two cases of spotted fever rickettsiosis in Kyushu. Kansenshogaku Zasshi 61:1166-1172. (In Japanese.)

17. Tyeryar, F. J., Jr., E. Weiss, D. B. Millar, F. M. Bozeman, and R. A. Ormsbee. 1973. DNA base composition of rickettsiae. Science 180:415-417.

18. Uchida, T., F. Mahara, Y. Tsuboi, and A. Oya. 1985. Spotted fever group rickettsiosis in Japan. Jpn. J. Med. Sci. Biol. 38:151-153.

19. Uchida, T., F. Tashiro, T. Funato, and Y. Kitamura. 1986. Immunofluorescence test with Rickettsia montana for serologic diagnosis of rickettsial infection of the spotted fever group in Shikoku, Japan. Microbiol. Immunol. 30:1061-1066.

20. Uchida, T., F. Tashiro, T. Funato, and Y. Kitamura. 1986. Isolation of a spotted fever group rickettsia from a patient with febrile exanthematous illness in Shikoku, Japan. Microbiol. Immunol. 30:1323-1326.

21. Uchida, T., Y. Tsuboi, A. Oya, T. Funato, and Y. Kitamura. 1986. Serologic studies of spotted fever group rickettsiosis occurring in Muroto-City, Kochi Prefecture. Kansenshogaku Zasshi 60:141-144. (In Japanese.)

22. Uchida, T., T. Uchiyama, and A. H. Koyama. 1988. Isolation of spotted fever group rickettsiae from humans in Japan. J. Infect. Dis. 158:664-665.

23. Uchida, T., X. J. Yu, T. Uchiyama, and D. H. Walker. 1989. Identification of a unique spotted fever group rickettsia from humans in Japan. J. Infect. Dis. 159:1122-1126.

24. Uchiyama, T., and T. Uchida. 1988. Ultrastructural study on Japanese isolates of spotted fever group rickettsiae. Microbiol. Immunol. 32:1163-1166.

25. Uchiyama, T., T. Uchida, and D. H. Walker. 1990. Speciesspecific monoclonal antibodies to Rickettsia japonica, a newly identified spotted fever group rickettsia. J. Clin. Microbiol. 28: $1177-1180$.

26. Yamamoto, S., N. Kawabata, T. Uchiyama, and T. Uchida. 1987. Evidence for infection caused by spotted fever group rickettsia in Kyushu, Japan. Jpn. J. Med. Sci. Biol. 40:75-78. 